\title{
7 Weathering Climate Change in Samoa: Cultural Resources for Resilience
}

Whether or not it has to do with climate change, Samoans have been adapting for a very long time. Leasiolagi Malama Meleisea, National University of Samoa, 2013

Julie glanced around the circle of workshop participants at the Museum of Samoa, the door behind her open onto a warm breeze and the ginger flowers decorating the entrance porch. She took a breath. "Look," she said:

we are the generation that is really going to have to deal with climate change. Losing the fale samoa is a pity, because we are losing our cultural gift, but for me, it is OK. We will have to adapt. We have to do what we have to do to survive. ${ }^{43}$

The fale samoa is the traditional house of Samoa (Figure 7.1). Open walled, with sturdy, smooth wooden pillars placed in an oval, holding up a high reaching, domed roof, all lashed together with strong coconut fiber, thatched thickly with palm leaves. Mata'afa Autagavaia, a Talking Chief and one of the Ministry of Education's cultural specialists, is particularly attached to the fale and all it stands for. He was part of the workshop circle. He leaned forward, into the challenge within Julie's summation of the issues pulling back and forth within everyday life in Samoa. "But," he said, "the fale is a safer house in a cyclone than a European house":

In a cyclone the palm fronds fly off and fly about, it is fun for kids. The sheet metal on the fale papalagi roof flies about and kills people. The fale in a cyclone sways-the sennit allows flexibility. The European house falls flat with no time to get out. Don't think that living in a new European house will make us safer. It won't. ${ }^{44}$

This statement is echoed in official circles: the sheet-metal fatalities of recent cyclones prompted the Head of State to call for beach fale resort owners to "build back better" after disasters, with safer, traditional pandanus roofing. Samoan doctoral student Anne Godinet-Milbank, working on a UNDP research project on Samoan architecture, found

43 J. L. L. Saia in discussion at "Rethinking Home: Climate Change in New York and Samoa" workshop, Museum of Samoa, Apia. 14-15 November 2013.

44 M. Autagavaia in discussion at "Rethinking Home: Climate Change in New York and Samoa" workshop, Ministry of Education, Sport, and Culture (MESC), National Government of Samoa. Apia, Samoa, 14-15 November 2013.

Jennifer Newell, Australian Museum 
traditional lashed arches and high-pitched roofs to be stronger in a cyclone (Samoa Observer, 25 September 2013). A UNESCO report stated the fale is "highly resistant to cyclones" (UNESCO, 1992: foreword). The fale samoa, strong and intricately-bound, can be seen to be a reflection of the strong and intricately-bound nature of Samoan society. Samoans think of themselves as part of a closely-connected whole, a strong structure of family and village, wrapped with cords of obligation, belonging, stories, histories; like the intricate patterns of the sturdy coconut fibre cords, ' $a f a$, lashing together the fale roof (Figure 7.2).

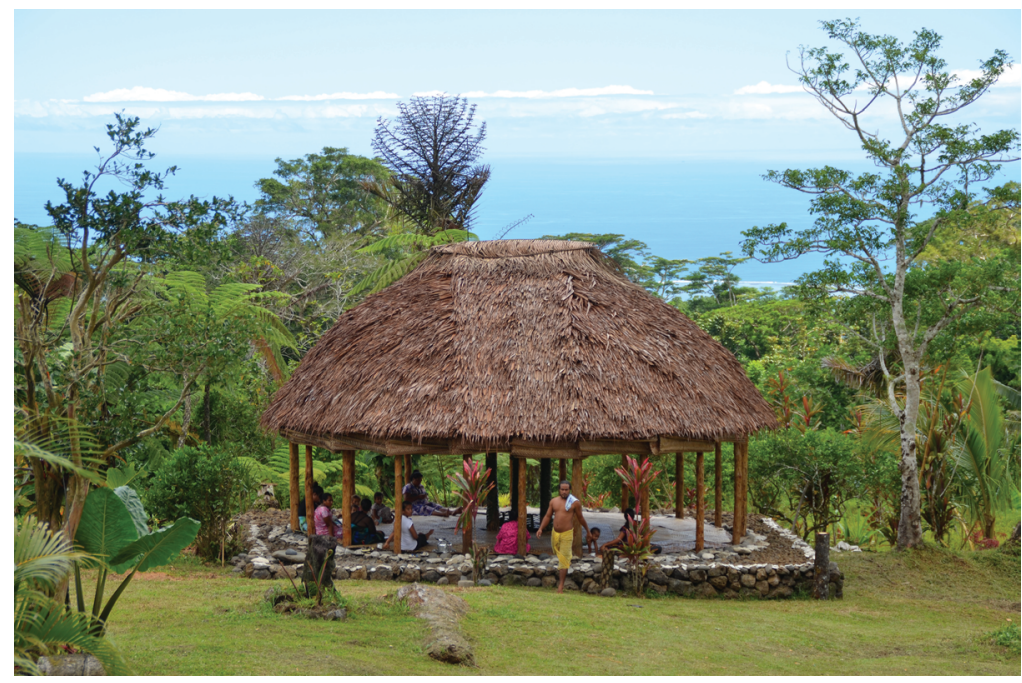

Figure 7.1: Fale talimalo (house for receiving guests) built by Laufale Faanu for the Tiapapata Art Centre, Apia, 2014. Photo: Steven Percival.

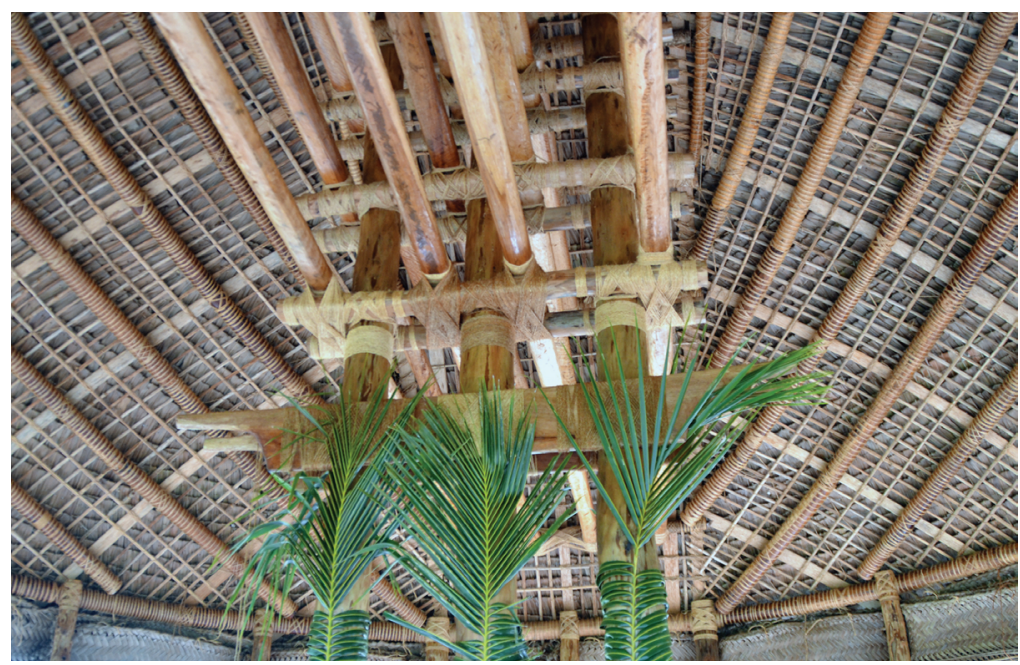

Figure 7.2: 'Afa binding on the roof structures in the fale at the Tiapapata Art Centre, Apia, 2014. Photo: Steven Percival. 
Dionne Fonoti, a visual anthropologist at the National University of Samoa, said to me recently, "Samoans don't do anything alone." This is both good and bad; a network of safety, security, and identity-and a web of surveillance, weighty expectations, restrictions and pressures to conform (Goodman, 1983; Lay et al, 2000). I am interested in finding out how these tightly-knit communities are approaching their climate changed world. What cultural resources-what pillars of strength-do Samoans have to support their wellbeing, in the way the pillars of a fale, the pou, hold up the roof? These questions have been at the core of the project "Rethinking Home: Climate change in New York and Samoa," a partnership between the American Museum of Natural History (New York) and the Museum of Samoa (Apia). The project, part of the U.S. State Department's Museums Connect program, has linked two coastal communities who have lived through severe tropical storms: Hurricane Sandy (October 2012) and Cyclone Evan (December 2012).

Moving beyond the usual focus of researchers on infrastructure and economic resources when considering a community's resilience to climate change, our project has been exploring how cultural and community structures provide psychological and social resilience. The cross-cultural learning from the project has been considerable, and is being published elsewhere. ${ }^{45}$ This chapter is a reflection on what we have learnt on the Samoan side. I should clarify that the "Samoa" I am talking about here is Independent Samoa, the ten islands (four inhabited) formerly known as Western Samoa. Most of the people we spoke to are on the island of Upolu, which holds the bustling capital, Apia, on its northern coast. Some of our informants were from Savai'i, the more forested and rural island. To the east of Samoa is American Samoa, fundamentally Samoan and the post-1900 intertwining with the US readily apparent. My research in Independent Samoa has begun recently: I have visited four times over 2013-2014, while working on the "Rethinking Home" project. I do not yet speak Samoan and I am fortunate that a wide range of people-villagers, university students, government employees and officers of NGOs-have been willing to speak to me in English.

Low-lying atolls have understandably been a focus of media attention and scholarship on climate change in the Pacific; Tuvalu and Kiribati have become poster children for the "front line" of climate change. ${ }^{46}$ However, communities on high islands are also experiencing radical life changes and wide-reaching impacts on lifeways, health and wellbeing. In Samoa, there are changes being felt in the higher tides eating into the land in which ancestors are buried, in the dying reefs, reducing the availability of food species, in the increasing heat and rising rainfall, in the droughts and the growing force of the cyclones hitting Samoa's coasts, washing

45 See www.amnh.org/our-research/anthropology/projects/rethinking-home 46 For important reflections on this issue see Orlove et al, 2014: 249-75. 
forests down hillsides and tearing through villages. In all of these are challenges to the way Samoans live on their land (Samoa Meteorology Division, 2013).

Like the inhabitants of Kiribati and Tuvalu, Samoans have been questioning how they should be living within their land. How to rebuild after a destructive event, how to adjust to fast-paced environmental change are issues that Samoans can't avoid. Climate change is also a very visible part of the Samoan administrative environment. The Secretariat of the Pacific Regional Program (SPREP) has its headquarters in Apia, and they distribute funds flowing into the Pacific from "Annexe 1" countries (those recognized under the Kyoto Protocol as the highest emitters). These nations send in funding for projects of assessment, mitigation, and adaptation. Each of the projects brings a swathe of consultants for surveys and climate change impact statements that need regular renewal. ${ }^{47}$

The Samoan Government has been distributing internationally-framed, locally corroborated information about climate change to the local population through radio, newspapers, posters and brochures, essay competitions and courses at the National University of Samoa. ${ }^{48}$ Messages focus on explaining climate change, strategies for mitigation and adaptation, with some statements about what it means for Samoa now and in the future. The issue of who is to blame is not centre stage. ${ }^{49}$

Samoa has signed the UN Framework Convention on Climate Change since 1992 (Government of Samoa, 1992, 1999). The Minister of Natural Resources spoke in Warsaw at CFCCC COP 19, November 2013 on Samoa being in the process of putting its "own house in order," with a National Greenhouse Gas Abatement Policy, and a target of being carbon-neutral by $2020 . .^{50}$ The Government has already exceeded its National Energy Policy target for renewable energy sourcing. After describing the intense tropical storms and other impacts of climate change Samoa is weathering, Dr le Tumaalii stated: "Climate is therefore an existential issue for Samoa" ${ }^{51}$ Climate change is experienced as a thoroughly "visible" phenomenon in Samoa, far from the "invisibility" that the global scientific community has long insisted upon (RudiakGould, 2013b).

47 M. Moneo, personal communication, Environment, Climate Change and Crisis Prevention and Recovery offices, United Nations Development Programme, Apia, 11 July 2013.

48 L. Apelu, personal communication, Museum of Samoa, Ministry of Education, Sport, and Culture (MESC), Samoan Government, Apia, 10 July 2013 and F. Latu, personal communication, National University of Samoa, Apia, November 2013.

49 On blame as a key dimension of how people engage in the issue of climate change, see RudiakGould, 2014a.

50 F. Tumaalii, Statement to the High Level Segment, 19th Conference to the Parties to the Framework Convention on Climate Change, UNFCCC/CMP9, Warsaw, 21 November 2013.

51 Tumaalii, Statement, 2013. 


\subsection{Sources of Resilience}

Resilience to climate change can be seen as a combination of cultural and ecological resilience (Peterson, 2000; Adger, Brown, Nelson et al, 2011). Cultural resilience encompasses the ways a society and its individuals are fitted to deal with environmental changes and challenges by virtue of their cultural mores, belief systems, their social, religious, economic and political relationships and capacities. Ecological resilience comes down to the capacity of an ecological system, including its people, to bounce back from a changing set of physical parameters.

I am most interested in cultural resilience, and within this, the capacity that Samoans (or any other group) have to manage their "interior" (psychological) world and manage their "exterior" (physical) environments, to deal as effectively as possible with climate change. By managing their interior world, I mean managing their wellbeing as individuals, families, villages and as a society as a whole. This encompasses the extent to which at each of these levels people maintain senses of security, solidarity, identity, clarity of purpose, and other positive feelings.

Samoans recognize that an important part of their resilience is contributed by their culture, “The Samoan Way": fa'a Samoa (see Meleisea, 1987). Fa'a Samoa is a particular, Samoan, approach to living. It is at heart the strong social cohesion; ways of relating to each other and to environments; customs and material culture; long traditions of being both rooted in land and effective in migration; and a capacity for adaptability.

The conversation between Julie and Mata'afa reflects the extent to which climate change is heightening the challenges that "modernity" poses to fa'a Samoa. While there is a sense that the environment has always been full of dangers, there has been a slow rise over the past few decades of an extra swathe of serious threats to families, homes and landscapes, and a threat to the practice of customs. ${ }^{52}$ People are assessing their safety and security, and how they lead their lives, now and into the future. Here, as elsewhere, climate change is a "threat multiplier" (Crate and Nuttall, 2009).

How each family approaches these increasing threats-what blending of holding onto traditions, or adopting new ideas and things-is variable. A physical manifestation of the fluid and contested nature of how a Samoan individual can be in the world can be seen in the way fale are a fluid and contested form, especially now that people are feeling the need for more physical security. Many Samoan families retain at least one traditional-style fale on the family land, in its open-walled, shady, breezy structure made of local materials, offering open hospitality, a public monitoring of behaviour, and embodying a sublimation of individual life to the larger family (Franco and Mageo Aga, 1997). Often the other houses on the family land are

52 L. Duffy-Iosefa, interview with J. Newell at Conservation International main office, Apia, 10 July 2013. 
built with iron roofs and more protective, private, enclosing walls of concrete blocks and glass windows. ${ }^{53}$ One of the participants in the "Rethinking Home" workshop at the Museum of Samoa had energetically defended the centrality of the traditional fale for maintaining Samoa's cultural strength and social accountability, but said quietly to me afterwards, "actually, I couldn't live in a fale. I have to keep my children safe."

One can see these dynamics in terms of an interplay between, on the one hand, a conceptual "pathway" from the land and from the past, which brings traditional ways of being (and which is generally given the moral high ground), and on the other, pathways from across the ocean, bearing different ways of being, thinking, and a degree of kudos attached to cosmopolitan attainments. ${ }^{54}$ These new pathways have arrived over time on canoes from other Pacific islands, tall ships from Europe, steamers from America, warships, airplanes, with travellers, traders and invaders. The original Samoan conception of the universe being contained within a dome of the sky, ending at the horizon (Lay et al, 2000), was broken through by white papalagi voyagers in the 1700 s. ${ }^{55}$ Since then the paths from the outside world have offered up ideas like Christianity and Western science; techniques like timber milling and wage labour, and goods of utility and desire: cotton cloth, tinned beef, cars, sunglasses and mobile phones. These things fall into a category that is spoken of locally as "modernity," papalagi, or more casually pālagi. How one walks the ancient path from the land, and whether one merges or ignores the paths that have landed from overseas, has long been the subject of energetic debates, discussions, and individual, everyday accommodations. It has always, and perhaps always will, cause a sense of loss for many Samoans when new ways cover over the old. As a character in Sia Figiel's Where We Once Belonged says: "Each time a child cries for Coca-Cola instead of coconutjuice the waves close into our lungs. Each time we choose one car, two cars, three cars over canoes and our own feet, the waves close in further..." (Figiel, 1996: 234).

The ways that people are thinking about climate change in the Pacific often has at heart a consideration of these paths, in any community you might travel to, amongst any group of people you might sit down and talk to or tune into on the radio or online. Peter Rudiak-Gould's work demonstrates it is this dynamic between tradition and modernity that is at the heart of how Marshall Islanders are engaging with climate change (2013a, 2014a).

53 For a discussion of the changing form of the Samoan fale, see relevant chapters in: Rensel and Rodman, 1997; Neich, 1985; Allen, 1993.

54 See Thomas (2010) for the history of Samoans and other Pacific Islanders enganging with the outside world, especially through travelling, and their complex negotiations between the value of the local and the exotic.

55 According to Kramer, papalagi means literally "sky breakers"-from $p \bar{a}$ : to to penetrate, break forth, and lagi: sky (Kramer, 1994: 27). However, whether the missionaries who originally recorded this term misunderstood it is a matter of discussion by historians. See particularly Tcherkézoff, 2008: $187-202$. 


\section{2 "Nothing New": A Tradition of Adaptability}

While many Samoans might find the losses of tradition and continuity that accompany climate change are upsetting, one of the key features that Samoans identify within themselves, with pride, is adaptability. This is seen as a pan-Pacific trait, entailing a capacity to manage living in a difficult, changing environment. Leilani Duffy-Iosefa, Terrestrial Program Manager at Conservation International, has said:

Climate change is nothing new: it is just a Western concept now being put onto environmental changes. People have always adapted to changes. ${ }^{56}$

Samoans feel they have maintained an ability to make adjustments to ways of life, and also to take on the changing potentials offered by the wider world, incorporating them into the fa'a Samoa. There is some hope and some sense of control that can be gleaned from both holding onto old ways and embracing technology from the outside world: cleaner energy and transport systems, "climate proof" houses and roads, seawalls-industrial solutions to the blight caused by the industrial age.

Many people see taking on new technologies as an important part of the capacity of Samoans to observe, predict, react to a changing and increasingly unpredictable environment: "we need our high technology, our machines - our warning systems," as one of the students at our workshop said. ${ }^{57}$ Filomena Nelson, director of Samoa's Disaster Management Division in the Ministry of Natural Resources and Environment, has talked about a recent study showing Samoan fale to be more resilient than fale pālagi. She said she understands this, but also understands the impetus to adopt the new:

... it's also because we're becoming westernized; we can't really be isolated from what's going on. We're connected through technology and everybody wants to be like other people in other countries. ${ }^{58}$

As we saw in Julie and Mata'afa's comments, modernization is seen to be both shoring up and eroding the capacity of Samoans to cope with climate change. Many villagers choose to use funding from international bodies to install solid, tangible defences against the encroaching waters. These are reassuring. But this intervention changes existing hydrological dynamics, slowing the release of flood waters, creating more serious flooding. ${ }^{59}$ One commentator stated:

56 Duffy-Iosefa, interview, 2013.

57 S. Lemalu, discussion at "Rethinking Home: Climate Change in New York and Samoa" workshop, Museum of Samoa, Apia, 11 June 2014.

58 Interview with J. Lacey, Ministry of Natural Resources and Environment, Apia, 22 November 2013. 59 Moneo, personal communication, 2013. 
There is so much funding out there for Small Island States for Climate Change, but it deals with a short time frame. Sea walls are funded-but these create more damage. We need to concentrate on trees. I'd seriously encourage more natural solutions. If people could focus on their cultural values that would help, looking to what worked in the past to adapt. ${ }^{60}$

This approach is one that is increasingly being promoted in Samoa and more broadly. A leaflet produced by SPREP on "Ecosystem-based adaptation" describes "natural solutions for resilience" such as ensuring plant cover on slopes and shorelines for protection from natural disasters and supplying a range of "ecosystem services," compared to no adaptation, or "hard engineering" adaptation options such as dredging and sea walls-which can damage biodiversity and coastal ecology (Figure 7.3). It will be interesting to see how well this proposed program plays out; it at least has the advantage of being more likely to be effective as it relies on the knowledge and activity of the people most intimately connected with the place, rather than being entirely dictated and directed by outsiders (Crate and Nuttall, 2009).

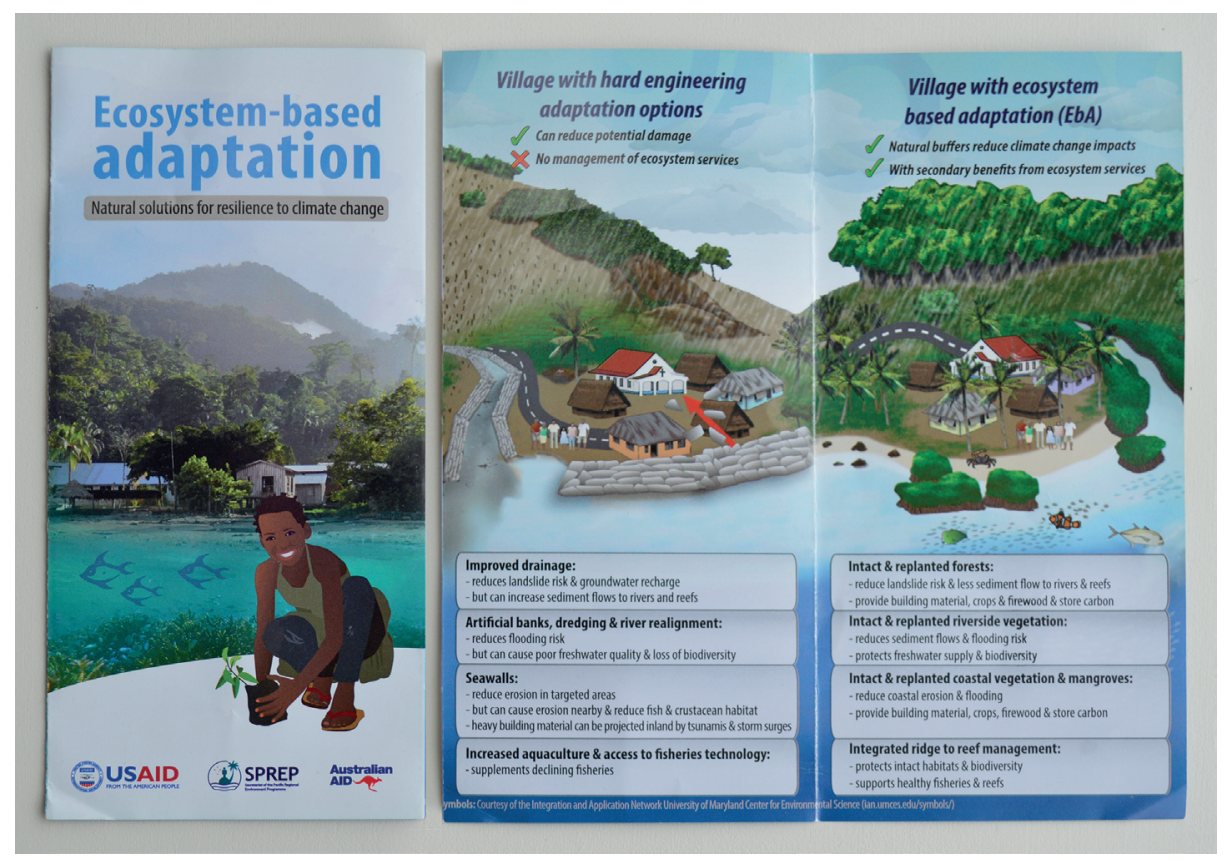

Figure 7.3: Brochure. “Ecosystem-based adaptation.” Secretariat of the Pacific Regional Environment Program (SPREP), 2014.

60 Duffy-Iosefa, interview, 2013. 


\subsection{It is Not 'I' but 'We'}

When you ask Samoans about what helped them cope with the recent intense storms and floods, and the 2009 tsunami, they immediately cite their family. The centre of life in Samoa is the extended family and the surrounding community: cohesive, coherent, co-operative. That it is not about "I" but "we" is often mentioned to outsiders. ${ }^{61}$ It is a state of being that Sia Figiel, in her novel Where We Once Belonged (1996), lays bare in her protagonist's moment of crisis: "Alone. For the first time I am alone. I am alone. I am 'I' in its totality-'I' without 'we'.” (Figiel, 1996: 236). Filomena Nelson, director of Samoa's Disaster Management Division, said:

\footnotetext{
Samoa is a communal society and that's a safety net for us in times of crisis. We value the support of our families and from our neighbours as well. It's part of our culture, it happens every day on a day-to-day basis. ${ }^{62}$
}

Belonging to a multi-generational family and close-knit community provides a strong sense of identity, a clear framework and sense of purpose for the individual to fit into. It also provides an easily-coordinated body of people to deal with a crisis, a range of able-bodied people to care for young and old, and a structure for managing every day matters. The main building-block of this structure is the 'aiga, the extended family, a lineage (Lay et al, 2000; Meleisea, 1987). The larger one's 'aiga, the more power and security one has. A collection of 'aiga, working together in one place creates a nu'u (village). The head of each 'aiga is the matai (chief) (Lay et al, 2000). The matai represents the family on the fono: the village council. These leaders meet under the roof of the large village faletele to resolve disputes, mete out punishments, organize events, keep the village working. The head of all the matai is the high chief, the ali'i. There are also tulafale "talking chiefs," or orators, and the pulenu'u, like a mayor, is an intermediary between village and government. The primary binding for this community cohesion is respect for elders and leaders (Lay et al, 2000).

\subsection{A Higher Power}

The respect for leaders extends to include the leaders of the church, the faife'au (pastor). Samoa is a very Christian nation. From the 1830s the religion had the support of the high chief Malietoa from soon after the arrival of missionaries (1830), as there had been a prophecy about the arrival of a new "kingdom of heaven" (Henry, 1980). Churches of various Christian denominations are a dominant and visible part of the

61 Apelu, personal communication, 2013.

62 Nelson, interview, 2013. 
village landscape, sitting tall amongst the fale (Figure 7.4). Sundays are dedicated primarily to worship, the community attending church dressed in white. As in any religious community, the presence of a divine force is a great source of confidence that things are under control, providing a sense of being looked after. Our discussions at the Museum of Samoa made clear the extent to which, across multiple generations, the Church provides significant psychological wellbeing for dealing with natural disasters and the stresses of a changing environment.

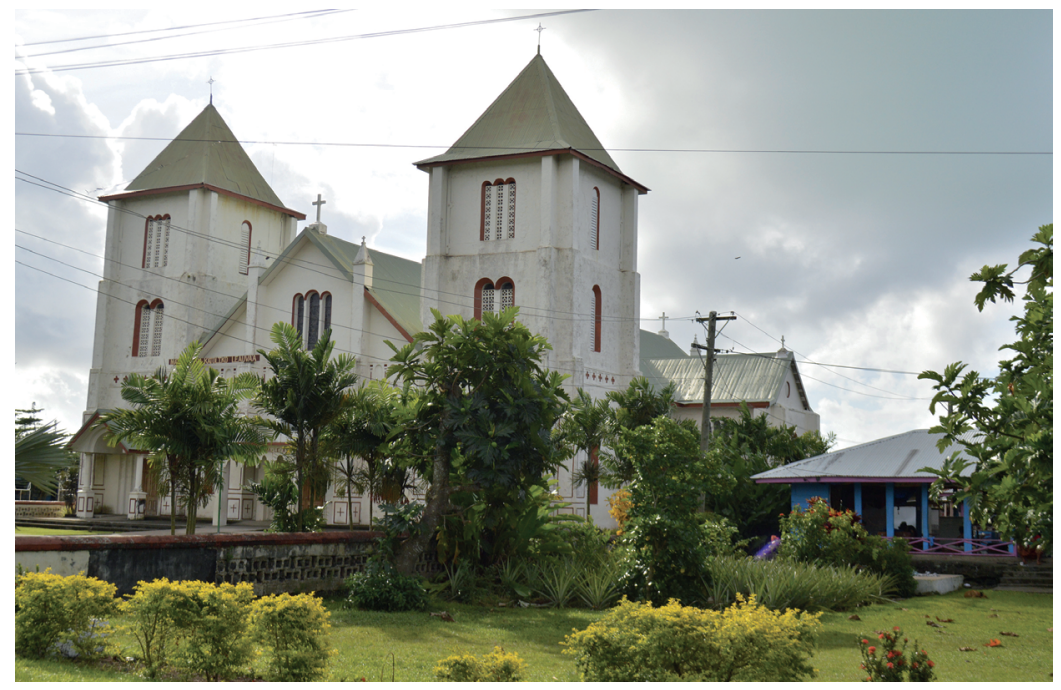

Figure 7.4: Village church, northern coast of Upolu, Samoa, 2014. Photo: Jennifer Newell.

\subsection{Skilled Voyagers, Rooted to Place}

One question I had at the start of the "Rethinking Home" project was whether Samoans see themselves as being part of the great tradition of Pacific voyaging, and if this can be seen as one of the cultural pillars supporting them as their land comes under increasing threat. I wondered if they feel connected to a Pan-Pacific voyaging heritage, gaining strength and a sense of being able to feel at home in any part of the "Sea of Islands" as Epeli Hau'ofa advocated (Hau'ofa, 2004), rather than being isolated by colonially-imposed boundaries.

Being Pacific voyagers is not something that sprang immediately into words for those I spoke to. A bit more questioning, however, revealed that many were aware of, and valued, their voyaging ancestry. There is a sense of a continuum in voyaging, and that while Samoans are rooted to place, they are skilled in modern modes of voyaging. Being able to travel around the world, to migrate effectively, to keep the link to 'aiga and home alive, to be successful wherever in the world they may go-is an ongoing part of what it is to be Samoan. Lumepa Apelu, my colleague at the Museum of Samoa, has said: 
Samoans are quite proud of being skilled migrators-that we can say there are Samoans in Alaska, there are Samoans all over the world. It is something we have always had-voyaging across the ocean...that ancestry is still within us. Voyaging was to trade, and we still do that. We trade, send back money and things, all for the 'aiga. ${ }^{63}$

For Dr Anne-Marie Tupuola-Plunkett, like many others of Samoan heritage, her grounded yet mobile connection with her homeland is central to her identity. "I'm a New Zealand-born Samoan, raised in Auckland, living in New York"-the poetic litany of connections underlines the way Pacific islanders have always lived. Annual inter-island long boat races (Lay et al, 2000) and the Samoan Voyaging Society in Apia reinforce this viewpoint. With their voyaging canoe Gaualofa, members of the Society were part of a fleet that travelled around the Pacific in 2012, supporting the revival of ancient navigation techniques and promoting the respect and care of the ocean. ${ }^{64}$ While voyaging heritage might not be a major part of the way Samoans see their armoury for dealing with climate change on the ground, a capacity to conceive of themselves as being able to stay connected despite moving away does contribute to how people approach the question of whether to stay or relocate. This could be seen as part of the concept of $\mathrm{Va}$, or the space of connection between things: between people, between people and the Creator, between people and the created world (Van der Ryn, 2007).

\subsection{On Family Land}

James Clifford has spoken of the extent to which people are now part of the world not so much as citizens of their singular nation as participants in routes between places that they trace throughout their lives (1997). It can be said that the strong role given to routes within the heritage of Pacific Islands makes it a trope that supports rootedness to home. In Samoa each 'aiga is deeply grounded and to a profound extent defined by a plot of ancestral land (Lay et al, 2000; Meleisea, 1987). The profound depth of connection that individuals possess in family and the family's land provides a deep-seated capacity to voyage well. They depart, but, in essence, they don't leave. Connections are kept alive through regular trips home, through phone calls, email and Facebook, through things sent home to support the 'aiga. Connection to family is also maintained for all those travelling by virtue of there being someone in the role of tausi 'aiga, the person who stays on the family land (tausi means "looking after"). ${ }^{65}$

63 Apelu, personal communication, 2014.

64 http://www.unesco.org/new/en/apia/about-this-office/single-view/news/gaualofa_crew_voyaging_across_the_pacific/\#.U7-pwRZ8PeI

65 Apelu, personal communication, 2014. 
The depth of the roots in both ancestral lands and in voyaging makes traveling away more possible to achieve with equanimity, with a sense of reinforcing and honouring a way of being and one's own identity. This can be seen as a cultural resource, a form of resilience that might swing into play in the future, when conditions can be expected to become more challenging.

The flip side of this is, however, that the ability to remain connected to family land, depends on being able to revisit-to pay respects to the esteemed ancestors buried in the front garden (Figure 7.5), to have the generations, living and dead, being kept together. If one cannot, in time, live on that land, voyaging takes on a different tenor. Becoming not a temporary stretching of the bond but a severance, a deep and irretrievable loss. This is a rising issue on low islands. "Failing to appreciate the uniqueness and irreplaceability of the islands," says Peter Rudiak-Gould, "is a common outsider's error” (2013a: 160). In the Marshall Islands, he writes:

Locals give disarmingly straightforward answers to the question 'Why is land important to Marshall Islanders?' It is survival, people say; that is all we have. For an outer islander, seeing your land destroyed would be like a westerner seeing his home burned down, being fired from his job, and losing his savings account all at once (2013a: 160).

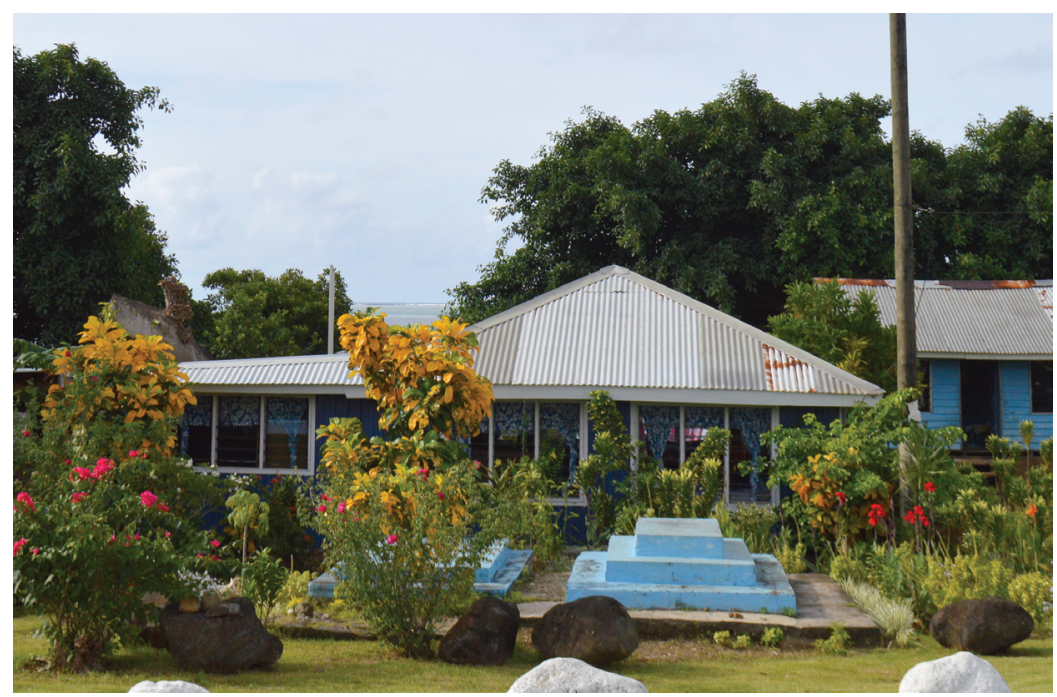

Figure 7.5: Fale with family grave in the front garden, northern coast of Upolu, Samoa, 2014. Photo: Jennifer Newell.

This sense of looming loss of everything is something that is not unknown in high islands. One of the environmental science students in our "Rethinking Home" group, when I asked what she imagined life would be like twenty years in the future, said it would be sad, because Samoa would be under water, many Samoans will have left, and those that couldn't leave will have drowned. 
Samoans are negotiating these dilemmas, and taking up their positions. Faainu Latu, Environmental Science lecturer, NUS, has summarized this process, and the resources that people have for taking steps:

\footnotetext{
Obviously there are people...people who have given up already: 'let's go, let's move, let's migrate to NZ /Australia, we'll be safe there-if we stay here in Samoa we're just going to lose our land, we're going to sink'. But there are on the other part of the scale the people are willing to adapt and do things like move inland. And it won't be so bad because we'll do things that will enable us to survive... Now our greatest assets are our people. ... [there is] our knowledge, traditional knowledge-and if you haven't noticed, there's a bond especially within families and between families... ${ }^{66}$
}

All these bonds have implications in a place increasingly threatened by natural disaster. One of the members of our Samoan group laughingly said, of the Cyclone Evan evacuation order: “I'm not the evacuating type. No, I didn't go-I needed to stay and look after the family land." She survived being in the heart of the storm and floods; others didn't. A research group recently found villagers expressed an unwillingness to move from increasingly dangerous areas for two key reasons. One, attachment to place: "we can't relocate-this is our land from our ancestors" (Male resident, Siumu West. Govt. of Samoa, 2013). Two, there was a lack of other options: "I am not sure where to go” (Male resident, Falefa, Anoama'a. Govt. of Samoa, 2013). Anyone who arranges to relocate to another family's land lives as an exile, uncomfortable, "not free". ${ }^{67}$ Dionne Fonoti, anthropologist at NUS, has said it could be argued that it is precisely:

because Samoans feel like land is their inheritance they move around, whether it's underwater or not. I'm not convinced that Samoans will leave Samoa or move because they're afraid of the elements. I think they're more apt to move because of their conviction that this land has and always will always be theirs and no matter what happens they can always come back to it. ${ }^{68}$

\subsection{Managing the Tangible World}

Aspects of the fa'a Samoa that support the effective management of the tangible, changing environment help people and their environments to bounce back from environmental disaster and protect existing systems (such as terrestrial and marine ecosystems and food production systems). Having the matai to oversee work on the lands belonging to the village, along with the village "workgroups"-the 'aumāga (untitled men) and aualuma (unmarried women) (Franco and Mageo Aga, 1997)-to

66 Latu, personal communication, NUS, Apia, 2013.

67 Apelu, personal communication, 2014.

68 Fonoto, personal communication, 2015. 
coordinate efforts to re-establish mangroves or to clean up after a cyclone, is an effective management approach, often operating in consort with government programs.

As we saw above, Samoans are deeply rooted in their landscape. Their original, pre-Christian legends of the creation of the island and the powerful beings that animate it might have receded in their potency, but there is still a foundation of awareness of the landscape being created by a pantheon of gods and other sacred beings. While these beings tend to now be classified as "demons" and young people report that their parents will get angry if they ask about them the legends are still part of the bedrock of conceptions of the island. ${ }^{69}$ Some commentators report on a continuance of an integrated system of understanding, with ancestors at its core: Penehuro Fatu Lefale writes: "Samoans view the environment as a total, integrated system, with many weather and climate phenomenon being directly caused by activities of ancestral beings" (Lefale: 323$){ }^{70}$

Certainly, some conception persists of the ancient, mutually-generative, intermingled, lustily intertwining couplings, and devastating battles between spirits, animals, people, rocks, sea, land. Writing of gods, Sia Figiel explains Pili could manifest himself "in any state of godliness he wished...manifesting love in the form of a pigeon, lust in the heart of a hibiscus, strength in the eye of a wind, or beauty in the form of man" (1996: 139). Some Samoans talk of there being malevolent spirits that continue to live on in the environment, that are particularly present in forests and abandoned houses, that can creep up on you, and cause sickness, ma'i aitu. "People are frightened to venture into forests," Leasiolagi Malama Meleisea told me; "there is a proverb: 'We love the forest, but we fear the spirits.."72

There were once ways of indicating these presences and living with them safely, as well as managing the consumption of food species sustainably; at the Pitt Rivers Museum, Oxford, there is a set of "signs" of palm leaf plaited into a variety of shapes, some with strips of siapo (barkcloth) or coral incorporated (Figure 7.6). They were hung at the edge of an area that a chief was protecting through instigating a tapu (taboo), such as reserving a fishing area at a particular time, or placing a turtle nesting ground out-of-bounds (Luna, 2003). Retribution for transgression could be expected from the animals and spirits of the area. ${ }^{73}$

69 "Rethinking Home” workshop, Museum of Samoa, June 2014.

70 While some of his sources are historic, his understanding of Samoan conceptions has grown out of years talking to several chiefs in Savai'i.

71 Apelu, personal communication, 2014. Ma’i meaning sickness, aitu meaning ghost.

72 Interview with J. Newell at Center for Samoan Studies, National University of Samoa, Apia, 9 July 2013.

73 The signs were collected in Samoa by the missionary Rev. J. E. Newell, in 1887. He donated them to the Pitt Rivers Museum, with notes, in 1888. The practice of protecting a fishing ground or grove of trees or other food sources by marking the area with coconut leaf signs and keeping it protected by dint of the owners' status and the threat of attack by resident spirits can be seen across many parts of the Pacific. The practice of marking areas or species as rahui, restricted, is well documented in Tahitian history (Newell, 2010) and is an ongoing practice in the Cook Islands (Tiraa, 2006). There are signs on the coast of Rarotonga marking bays that are, at certain times, ra'ui. 


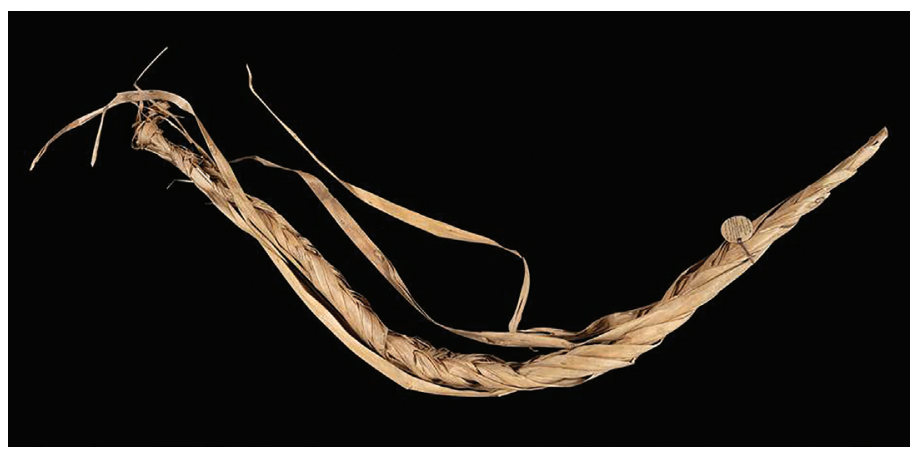

Figure 7.6: Tapui au, palm leaf figure of a gar fish (rar-aku) placed on trees or land by the head of a specific 'aiga, to protect a fishing area against theft. $87 \mathrm{~cm} \times 7 \mathrm{~cm}$, collected by Rev. J. E. Newell, London Missionary Society, Nov. 1887, Acc. No.1888.5.3, reproduced courtesy of the Pitt Rivers Museum, Oxford.

In a threatened environment, an ongoing, intimate, relationship between plants, animals and landscape, people and spirits, which involves the heart as well as the mind, can be seen to be an important resource. A relationship of closeness and respect for the power of things residing in the landscape is more likely to be a mutually-supportive relationship, arguably more likely to lead to people treating their environment with respect.

Traditional environmental knowledge (TEK) is a foundational resource in Samoa-as it is for many indigenous societies around the world (Crate and Nuttall, 2009; Nilsson, 2008). A recent study suggests that TEK is still important in Samoa for understanding and living with their changing environment. ${ }^{74}$ The MNRE has held workshops with elders to "pass on their knowledge...to share the knowledge that ancestors depended upon to forecast the weather, tides and other natural changes, before modern science took over." ${ }^{75}$ Their observations of signs such as cloud formations, bird calls, the behaviours of insects and marine creatures are being recorded for a reference book "to complement the knowledge of modern day climate studies” (Lefale, 2010; Newsline).

\subsection{Undermining the Fale Pillars}

There are aspects of the way Samoans tend to approach their world that erode the pillars supporting the wellbeing of their environment. Some of the academics, government and

74 The Study was conducted by the Samoan Government and the National Institute for Water and Atmospheric Research, New Zealand; see Lefale, 2010.

75 Newsline, 25 August 2013: 2, see also http: //media.bom.gov.au/social/blog/61/bureau-winsawards/ 
NGO workers working on climate change in Samoa have expressed a very real frustration at the 'blind spots' that many Samoans maintain. They feel there is a side-stepping of responsibility, and a shutting-off of previously-felt connections to the environment in order to engage in the timber industry, to fish on a large scale, to put in cash crops, to squeeze more money from the land and sea. Mata'afa Autagavaia (MESC) has said that in the past Samoans "were careful about using the environment...We got food from the forest. The forest was our factory. The trees are our brothers and sisters." He spoke of his sadness over the arrival in Savai'i in the 1960s of timber-getters from Oregon:

Our people rushed to get jobs. Cutting down the trees. The foreigners sold the bodies. Those that were not good enough were left on the ground to rot. It was like a graveyard. No birds...the land was desolate, like a battlefield. ${ }^{76}$

People are seen to be handing over responsibility to two higher forces: God and Climate Change. One academic expressed frustration at the changes in conceptual frameworks that accompany Christianity that allow people to abrogate responsibility:

The environment is not seen as something that needs to be preserved.... Samoans attribute natural disasters-storms, flooding, etc-to something supernatural...If you think the environment is controlled by God, then your relationships to the environment can be quite destructive. ${ }^{77}$

It is not uncommon for Samoans to feel that whatever happens is the will of God and it is not for people to try to change this decree. In a Samoan-made Youtube documentary about climate change, a manager of a beach fale resort stated: "Climate change is not man made but God's will. It is the nature of things and Samoans have come to understand this" (Lal, 2009)..$^{78}$ Many people feel that they should not be concerned about climate change: they are confident in God's promise to Noah, confident the world will not be flooded again.

Sunny Seuseu, chief climate scientist in MNRE's Meteorology Division, has said: "One of the difficulties and challenges that we face is communicating science to a very Christian nation and people". ${ }^{79}$ When he talks about climate change projections he is sometimes asked "about the confidence that can be placed in this," and also if he is "doing God's work"? He has to be "really innovative" and make clear links

76 Autagavaia, 2013.

77 Anon, Apia, 2013.

78 Feagaimalii Leupolu, manager of the Taufua Beach Fales (Lalomanu). He mentions that they were wanting to relocate the fales away, to avoid unpredictable disasters like cyclones and tsunami. As it happens, the family had started work on an uphill residence, but it was incomplete when a tsunami hit Lalomanu, two months after the documentary aired. There was great loss of life, including many members of the family that runs the Taufua Beach Fales.

79 S. Seuseu, interview with J. Lacey, Meteorology Division, MNRE, Apia, 18 November 2013. 
between the scientific narrative and what communities are "feeling in their day to day lives". 80

\subsection{Climate Change as a Cultural Resource}

The environmental workers in Samoa I spoke to feel that the concept of climate change has become a useful prop for people. On the one hand government bodies and villages can deploy the term to leverage funding from international funders. If a new road is needed, said one conservation worker, a village only has to say it is for climate change adaptation to secure funding. Climate change, as a label and an idea, is itself a useful resource for resilience to climate change, providing a way of supporting mitigation, flexibility and a way of dealing with a more constrained access to resources. ${ }^{81}$ The term is a convenient way for people to side-step personal, traditional, "ordinary" environmental responsibility. The Marine Program officer at Conservation International sees climate change being used as a "catch all," blamed for "everything from deforestation to less fish in the sea." 82 "Over the last 4-5 years," he says:

Climate Change has become a buzz word. People are saying there are not enough fish, because of climate change, not because of their fishing practices, not because they are overfishing and ignoring size restrictions (Van Dijken, 2013).

An all-pervasive scapegoat, it is drowning out former conservation efforts, says Leilani Duffy-Iosefa, of Conservation International:

Climate change is overused; biodiversity is now at the back of everyone's minds. Everything is climate change now. It is "climate change this, climate change that"...Climate change is an excuse for not taking responsibility for what people are actually doing. Especially in developed countries. It is not as well known elsewhere. In Palau they are more concerned with biodiversity and invasive species. ${ }^{83}$

The sense of Samoans having strayed from the original, traditional path of being part of the living, "natural" and spiritual world around them, of caring and being intimately intertwined was echoed by others. As an NUS lecturer said: "We have removed ourselves from nature. We need to insert ourselves back in” (2013).

80 Seuseu, interview, 2013.

81 With thanks to Tony Crook for contributing this point.

82 S. Van Dijken, personal communication, Apia, 9 July 2013.

83 Interview, 2013. 


\subsection{Conclusion}

This reflection on Samoan cultural resources for dealing with climate change has identified several pillars of strength. The 'aiga and villages; the matai system; the capacity for adaptation; skill in migration; rootedness in land; and some continuity of the ability to read the environment. There is also the potential for close integration with foundational concepts of a deeply changeable, intimately interconnected environment. We have explored some of the foundations of Samoan conceptions of themselves. We have explored the ways that Samoans see traditional practices, relationships and material things as a resource for dealing with climate change, and the ways some of the paths from the land have been overlaid or merged with paths from overseas. Some of the loss of old paths and changing to the new is seen to weaken Samoan resilience. Some taking of new pathways-particularly the adoption of remote sensing, computing, communications technologies and approaches to house building-are seen to bolster strength.

We can see that recognizing existing strengths within a community can help to shore up and extend what works. The alternative is to permit the common approach of having people from the outside-scientists, commentators, and analysts-decide on resilience indicators and responses (Cote and Nightingale, 2012; Fabinyi, Evans and Foale, 2014).

Knowing more about how communities see themselves, about their own resources for cultural and environmental resilience, is the type of learning we need as we all face an increasingly unpredictable and challenging world. Samoa's greatest resource for dealing with climate change is undoubtedly the solidarity of extended family and community. The 'aiga, as manifest in the fale samoa, is undoubtedly something Mata'afa would point to, and he would hope that the fale will continue, a material representation of all that he holds dear. He will continue to advocate the fale samoa as the safest house for Samoans. And Julie? She is now attending university in Aotearoa New Zealand. We can wonder where in the world, and in which ways, she will eventually create a home that will provide her with physical and emotional security. Where she and others of her generation will settle on the continuum between fa'a Samoa and pālagi and how they decide to deal with their climate-changed world, we shall have to wait and see. ${ }^{84}$

\footnotetext{
84 I am grateful to Lumepa Apelu (National Museum of Samoa), Jacklyn Lacey (AMNH), to Leasiolagi Malama Meleisea (National University of Samoa), Sunny Seuseu (MNRE) and Faainu Latu (NUS) for commenting on this chapter, to Mark Gunning (Gunningdesign.com) and Shelby Pykare (AMNH) for their support, and the many informants in Samoa who generously agreed to be interviewed for this research. I give special thanks to editors Tony Crook and Peter Rudiak-Gould for their inspiring work, for convening the original ESfO session and for their conceptual input to this chapter. I gratefully acknowledge the support of the U.S. State Department's Museums Connect program. This important program is made possible by the Bureau of Educational and Cultural Affairs and is administered by the American Alliance of Museums.
} 